\title{
Occurrence of bacteria in the primary oocytes of vesicomyid clam Calyptogena soyoae
}

\author{
Keiko Endow, Suguru Ohta \\ Ocean Research Institute, University of Tokyo, 1-15-1, Minamidai, Nakano-ku, Tokyo 164, Japan
}

\begin{abstract}
Intracellular procaryotic cells were consistently found in TEM observations of primary oocytes and follicle cells of the deep-sea seepage clam Calyptogena soyoae. These bacteria resembled gill endosymbionts in the following 3 points: dimensions and general outline, occurrence of electron-transparent vacuoles in the periplasm, and occurrence of electron-dense materials in the periplasm. Eggs which harbored bacteria were all in the vitellogenic stage. This finding suggests some restricted time schedule of the entry of bacteria into oocytes. It is hypothesized that these bacteria represent transmission stage of gill symbionts, and continuum of the symbiosis is maintained by maternal inheritance through egg infection.
\end{abstract}

Calyptogena soyoae harbors symbiotic bacteria in branchial epithelia (Endow 1988), like other vesicomyid clams such as $C$. magnifica, C. pacifica and $C$. elongata (Cavanaugh 1983, Vetter 1985). These bacteria have been found to be sulfur oxidizers and have been postulated to be important to the nutrition of host clams (Felbeck et al. 1981, Sakai et al. 1987). Because of their role in clam life, it is important to know the mode of establishment of the symbiosis in each new generation.

In endosymbiotic associations, symbionts can be acquired by an individual host through one of 3 ways: by acquisition of microorganisms from an environmental stock (Bauer 1981), by horizontal transmission (from symbiotic individual to aposymbiotic individual) (Soldo et al. 1974), or by vertical transmission (from one generation to offspring) (Buchner 1965).

Among chemoautotrophic symbioses, transmission of symbionts through egg infection, during a short phase of oviposition, was first reported for the shallow water oligochaetes Phallodrilus leukodermatus and $P$. planus by Giere \& Langheld (1987). Gustafson \& Reid (1988) observed in the shallow water gutless bivalve Solemya reidi that bacteria first occurred in the locomotory test cells of the larvae and then in the perivisceral cavity of post-larvae, but not in or on eggs. They hypothesized that the bacteria found in larvae might represent a transmission stage of the gill symbionts which had been introduced into eggs in cryptic forms. Among deep-sea species, Riftia pachyptila was concluded to establish symbiosis by taking up bacteria from freeliving environmental populations (Cary et al. 1989).

Through transmission electron microscopic studies of Calyptogena soyoae, we provide some new information relevant to the vertical transmission of symbionts in the deep-sea seepage clam.

Materials and methods. Samples of Calyptogena soyoae were collected on 3 November 1988 during Dive no. 379 of the Japanese submersible 'Shinkai 2000', from Sagami Bay off Hatsushima Island at a depth of $1160 \mathrm{~m}\left(34^{\circ} 59.9^{\prime} \mathrm{N}, 139^{\circ} 13.6^{\prime} \mathrm{E}\right.$ ) (see Hashimoto et al. 1989 for a general description of the seep field).

Four adult specimens ranging from 113.5 to $125.5 \mathrm{~cm}$ in shell length were used for this study. The clams were dissected within $5 \mathrm{~h}$ of being brought on board and pieces of ovary were fixed in a mixed-aldehyde fixative $10.5 \%$ paraformaldehyde and $2 \%$ glutaraldehyde in $0.075 \mathrm{M}$ cacodylate buffer at $\mathrm{pH} 7.4$ containing $0.19 \mathrm{M}$ sodium chloride) at $4{ }^{\circ} \mathrm{C}$ for $1.5 \mathrm{~d}$ followed by thorough washing with buffered sodium chloride. Post-fixation was performed in buffered osmium tetroxide (1\%) for $1.5 \mathrm{~h}$ at room temperature. Tissues were dehydrated through a graded series of ethanol followed by propylene oxide and then embedded in Epon. Ultra-thin sections were stained by uranyl acetate and lead citrate and then examined in a JEOL 100CX transmission electron microscope.

Results and discussion. Ovaries contained various stages of oocytes along with follicle cells. Like Calyptogena magnifica (Berg 1985), oogenesis of C. soyoae appears to be continuous.

Procaryotic cells with a Gram-negative type cell envelope were found within follicular tubules. Like gill 


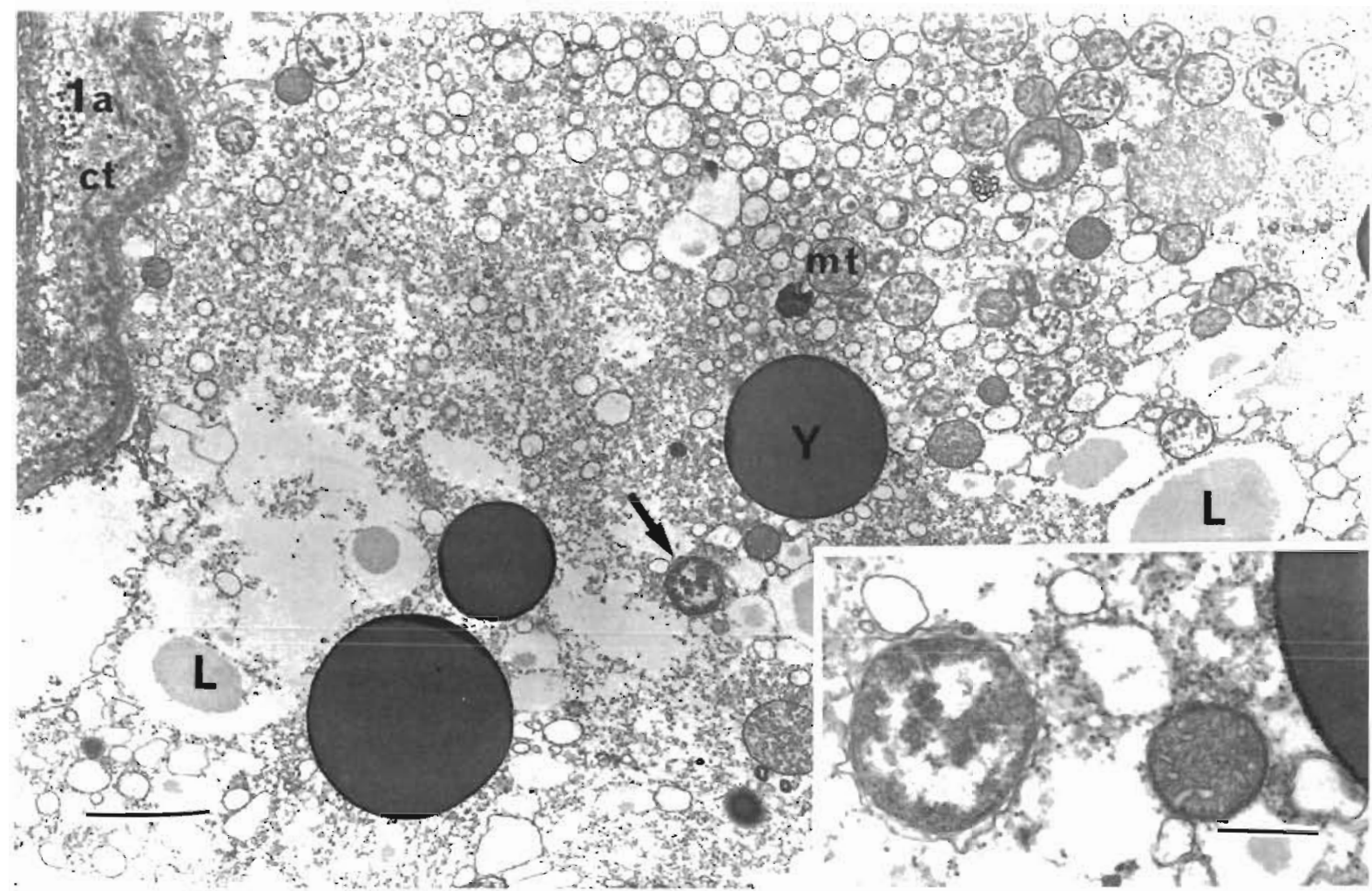

Fig 1 Calyptogena soyoae Bacterla in oocytes (a) Bacterium near the basement of vitellogenic oocyte (arrow). ct connective tissue surrounding follicle, mt mitochondna, L lipid droplet; $Y$ yolk granules; scale bar $=2 \mu \mathrm{m}$ Insert. Enlargement of the bactenum showng fine structure and enclosing vacuolar membrane, scale bar $=05 \mu \mathrm{m}$. (b) Bacterium with electron-transparent vacuole in periplasm (arrow), scale bar $=05 \mu \mathrm{m}$. (c) Electron-dense matenal deposited in periplasm (arrow), scale bar $=0.5 \mu \mathrm{m}$

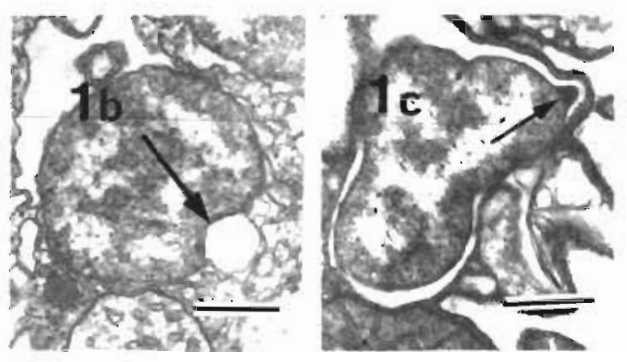

endosymbionts, a peptidoglycan layer was scarcely observed. Van Caeseele \& Lees (1969) reported that the Gram-negative facultative autotroph Thlobacillus novellus showed no peptidoglycan layer when grown autotrophically. All 4 clams harbored bactena in both vitellogenic oocytes (Fig 1) and follicle cells. In most cases, follicular tubules contained several bacteria, and un one case, up to 6 bacteria were found within a single primary oocyte on a single ultra-thin section. The bacterla inside the eggs and follicle cells were enclosed by a vacuolar membrane (Fig 1a, insert) which was probably of host ongin. Some of the bactena contained electron-transparent vacuoles in their penplasms (Fig. 1b) Electron-dense matenals were also observed in the perplasm of some of the bacteria (Fig 1c). These findings show the strong resemblance of the bacterla within the follicular tubules to gill endosymbionts (Fig. 2) reflected also by their sumlar.tıes in dimensıons and general outlines (Figs. 1 and 2).
This is the first observation that a host organism symbiotic with sulfur-oxidizing bacteria harbors bacterla in its primary oocytes. Occurrence of bacteria in ovary accessory cells is not unusual for a symbiotic host in which transmission of symbionts takes place vertically from mother to progeny. For example, in Calandra (Curculıonjdae; Insecta), the bacteria reproduce within nutrient cells and pass into oocytes through the nutrient chord when the nutrient cells begin to secrete nourishment into growing oocytes (Buchner 1965). In the scaphopods Dentalium dentale and D. antillarum, bacteria, which are present in the space between follicle cells and oocytes and probably also in follicle cells, appear to become attached to the vegetal pole of the eggs dunng the very short time of spawning (Timmermans et al 1970, Geilenkirchen et al. 1971)

Occasionally bacteria were found intercellularly However, we have not yet found bacteria in the oocytes of the previtellogenic stage, though much work is 


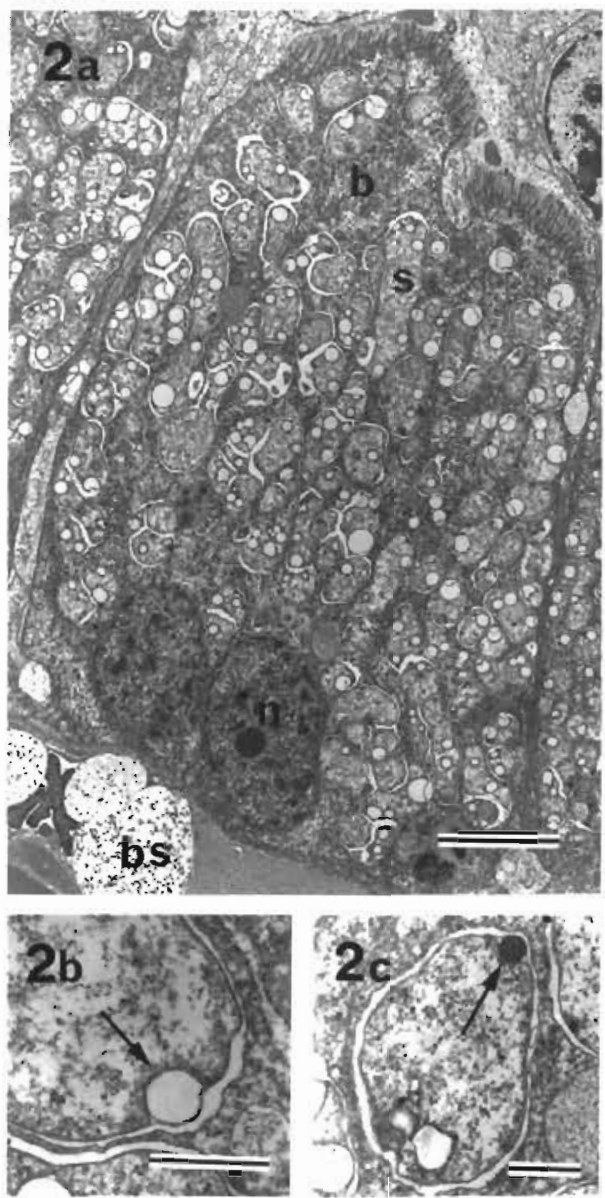

Fig. 2. Calyptogena soyoae. Bacteria in bacteriocytes. (a) Bacteriocyte occupied by abundant symbiotic bacteria. b: bacteriocyte; bs: blood space; n: nucleus; s: symbiont; scale bar = $5 \mu \mathrm{m}$. (b) Transparent vacuole in the periplasm of endosymbiont (arrow); scale bar $=0.5 \mu \mathrm{m}$. (c) Electron-dense material at upper right of bacterium (arrow); scale bar $=0.5 \mu \mathrm{m}$

needed to confirm the absence of bacteria in previtellogenic oocytes. This suggests some regulated mode of infection, especially in time of entry into oocytes.

These observations strongly suggest that the bacteria found in the primary oocytes of Calyptogena soyoae represent transmission stage of gill endosymbionts. Symbiotic bacteria in $C$. soyoae appear to be passed vertically from mother to offspring by means of egg infection.

Acknowledgements. We thank the 'Shinkai 2000 ' operation group and the captain and crew of the tender ship Natsushima' of JAMSTEC, for the valuable support in carrying out the investigation. We also thank Dr T Gamo for his effort

This note was presented by Professor N. D. Holland, La Jolla, California, USA in collecting Calyptogena soyoae. We are indebted to Dr K. Ohwada for helpful comments on the manuscript. This study was aided by Special Coordination Funds of the Science and Technology Agency of Japan.

\section{LITERATURE CITED}

Bauer, W. D. (1981). Infection of legumes by rhizobia. Ann Rev. Plant Physiol. 32: 407-449

Berg, C. J. Jr (1985). Reproductive strategies of mollusks from abyssal hydrothermal vent communities. Bull. Biol. Soc Wash. 6: 185-197

Buchner, P. (1965). Endosymbiosis of animals with plant microorganisms. Interscience Publ., New York

Cary, S. C., Felbeck, H., Holland, N. D. (1989). Observations on the reproductive biology of the hydrothermal vent tube worm Riftia pachyptila. Mar. Ecol Prog. Ser 52: 89-94

Cavanaugh, C. M. (1983). Symbiotic chemoautotrophic bacteria in marine invertebrates from sulphide-rich habitats. Nature, Lond. 302: 58-61

Endow, K. (1988). Symbiosis of marine invertebrates with chemoautotrophic bacteria. Heredity 42: 50-53 (in Japanese)

Felbeck, H., Childress, J. J., Somero, G. N. (1981). CalvinBenson cycle and sulphide oxidation enzymes in animals from sulphide-rich habitats. Nature, Lond. 293: 291-293

Geilenkirchen, W. L. M., Timmermans, L. P. M., Van Dongen, C. A. M., Arnolds, W. J. A. (1971). Symbiosis of bacteria with eggs of Dentalium at the vegetal pole. Exptl. Cell Res. $67 \cdot 477-479$

Giere, O., Langheld, C. (1987). Structural organisation, transfer and biological fate of endosymbiotic bacteria in gutless oligochaetes. Mar Biol. 93: 641-650

Gustafson, R. G., Reid, R. G. B. (1988). Association of bacteria with larvae of the gutless protobranch bivalve Solemya reidi (Cryptodonta: Solemyidae). Mar Biol. 97: 389-401

Hashimoto, J., Ohta, S., Tanaka, T., Hotta, H., Matsuzawa, S. Sakai, H. (1989). Deep-sea communities dominated by the giant clam, Calyptogena soyoze, along the slope foot of Hatsushima Island, Sagami Bay, central Japan. Palaeogeogr. Palaeoclimatol. Palaeoecol. 71: 179-192

Sakai, H., Gamo, T., Endow, K., Ishibashi, J., Ishizuka, T., Yanagisawa, F., Kusakabe, M., Akagi, T., Igarashi, G., Ohta, S. (1987). Geochemical study of the bathyal seep communities at the Hatsushima site, Sagami Bay, Central Japan. Geochem. J. 21: 227-236

Soldo, A. T., Godoy, G. A., Brickson, S. (1974). Infectious particles in a marine ciliate. Nature, Lond 249: 284-286

Timmermans, L. P. M., Geilenkirchen, W. L. M., Verdonk, N. H. (1970), Local accumulation of Feulgen-positive granules in the egg cortex of Dentalium dentale L. J. Embryol. exp. Morph. 23: 245-252

Van Caeseele, L., Lees, H. (1969). The ultrastructures of autotrophically and heterotrophically grown Thiobacillus novellus. Can. J. Microbiol. 15: 651-654

Vetter, R. D. (1985). Elemental sulfur in the gills of three species of clams containing chemoautotrophic symbiotic bacteria: a possible inorganic energy storage compound Mar. Biol. 88: 33-42

Mãnuscript first received: August 15, 1989

Revised version accepted: April 9, 1990 